\title{
Paclitaxel as an anticancer agent: isolation, activity, synthesis and stability
}

Vesna D. Nikolic ${ }^{1 *}$, Ivan M. Savic ${ }^{1}$, Ivana M. Savic ${ }^{1}$, Ljubisa B. Nikolic ${ }^{1}$, Mihajlo Z. Stankovic ${ }^{1}$, Valentina D. Marinkovic ${ }^{2}$

${ }^{1}$ Faculty of Technology, University of Nis,

Bulevar oslobodjenja 124, 16000 Leskovac, Serbia

${ }^{2}$ Faculty of Pharmacy, University of Belgrade,

Vojvode Stepe 450, 11000 Belgrade, Serbia

Received 1 April 2011; Accepted 14 June 2011

Abstract: Paclitaxel is isolated from the Pacific yew. It can be obtained from the European yew, but only after chemical modification of the isolated
compound by a semi-synthesis procedure. The procedure for total synthesis of paclitaxel is very complicated, involving multiple steps,
and the yields of paclitaxel are meagre. This substance is also a metabolite of certain kinds of fungus. The microbiological pathway
for producing paclitaxel compared with isolation from plant material involves shorter procuction times but a small yield. Cyclodextrins
are usually used for improving the solubility of paclitaxel in aqueous media, with polymeric and other substances added. Paclitaxel has
anticancer activity and use for preparing the formulations intravenously administrated to patients with tumors. The paclitaxel concen-
tration in these formulations is determined using validated HPLC methods.
Keywords: Paclitaxe/ • Isolation • Activity • Synthesis • Complexation
(C) Versita Sp. z o.o.

\section{Nature sources of paclitaxel}

The National Cancer Institute analyzed the content of an extract from a bark of Pacific yew (Taxus brevifolia), first isolated from a plant material in 1963 [1]. The Pacific yew is a rare, low-growing evergreen plant, locating in the old forests of the northwestern Pacific. Preclinical studies of the extract showed that it had a cytostatic activity on many types of tumors [2]. In 1971, paclitaxel was identified as an active constituent of this extract. Development of paclitaxel for medicinal use proceeded slowly despite its antitumor activity because collecting sufficient amount required much time and plant material (for about $1 \mathrm{~kg}$ yield, it is necessary to isolate the extract from 3,000 of Pacific yew trees). Interest in this substance was aroused in 1979, when its mechanism of action as an antitumor drug was identified [3-5]. Paclitaxel is also contained in Taxus yannanensis, and has been obtained from Taxus baccata by semi-synthesis.
Stierle et al. [6] indentified the fungus of Taxomyces andreanae that produces paclitaxel. Although the yield of paclitaxel was tiny $\left(24-50 \mathrm{ng} / \mathrm{dm}^{3}\right)$, this discovery was of major interest to scientists [7]. Several procedures have been suggested for isolation from the endophytic fungus [8-10], showing that microorganism of Taxus species can produce paclitaxel. Therefore, the process of fermentation using a paclitaxel-produced microorganism represents an alterative procedure for paclitaxel production. The major problems involved in fungus fermentation are the very small yield of paclitaxel and its instability: the yields ranged from $24 \mathrm{ng}$ to $70 \mu \mathrm{g}$ per liter of the investigated fungus [6,8]. The microspore of Pestalotiopsis CP-4 [9] produced paclitaxel from 50 to $1487 \mathrm{ng} / \mathrm{dm}^{3}$. The goal of the present research is discovering the optimal fermentation conditions for Taxus cell cultures.

Although the amount of the produced paclitaxel from fungus was lower than those that were obtained from 
yews, the shorter production time and high rate of fungus growth have had an important role in further studies. After almost two years of research, scientists have isolated several endophytic funguses from Taxus chinensis var. mairei and Taxus yunnanensis. Species of Ozonium BT2 can also produce paclitaxel and taxane baccatin III (intermediates in the production of paclitaxel).

Production of paclitaxel by a microbiological pathway is also possible using a pure culture of Actinomycetes [11]. Microorganisms from the Actinomycetes group usually belong to the suprageneric group of Streptomycetes, Actinoplanetes, Maduromycetes, Thermomonosporas or Nocardioforms, but more often to the Streptomyces, Actinoplanes, Nocardiopsis, Micromonospora, Actinomadura or Kitasatosporia genus, and mostly to the Kitasatosporia genus. Among them, the most significant is Kitasatosporia sp. CECT 4991.

\section{General characteristics of paclitaxel}

The IUPAC name for paclitaxel is $(2 \alpha, 4 \alpha, 5 \beta, 7 \beta, 10 \beta, 13 \alpha)$ 4,10-bis(acetyloxy)-13-\{[(2R,3S)-3-(benzoylamino)2-hydroxy-3-phenylpropanoyl]oxy\}-1,7-dihydroxy-9oxo-5,20-epoxytax-11-en-2-yl benzoate. Its structural formula is shown at Figure 1, and Table 1 lists its characteristics.

Paclitaxel is soluble in dimethyl sulfoxide (DMSO) $\left(50 \mathrm{mg} / \mathrm{cm}^{3}\right)$ [6]. A $0.01 \mathrm{~mol} / \mathrm{dm}^{3}$ solution of paclitaxel in DMSO has been stored as aliquots until use and further diluted to $10^{-10} \mathrm{~mol} / \mathrm{dm}^{3}$ with medium [12]. Paclitaxel is also soluble in methanol $\left(50 \mathrm{mg} / \mathrm{cm}^{3}\right)$. It undergoes hydrolysis and transesterification to $\sim 30 \%$ of the peak signal at $227 \mathrm{~nm}$ by a high performance liquid chromatography method (HPLC) after two weeks at room temperature. Paclitaxel is rapidly destroyed in weakly alkaline, methanolic solutions and in strongly acidic methanolic solutions (1:1 of methanol : concentrated $\mathrm{HCl}$ ). A sample with $0.1 \%$ acetic acid added to methanol showed no signs of degradation for seven days at room

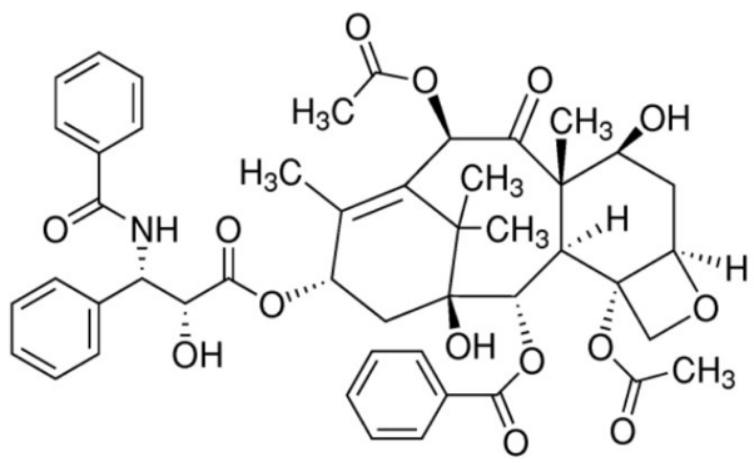

Figure 1. Structural formula of paclitaxel temperature or three months at $4^{\circ} \mathrm{C}$ (presumably due to the ability of the acetic acid to neutralize traces of alkali in the methanol) [13]. Paclitaxel is also soluble in ethanol and acetonitrile [14].

Paclitaxel has low solubility in water and is rapidly destroyed in weakly alkaline aqueous solutions [13]. The lowest amount of degradation in aqueous paclitaxel solutions occurs in $\mathrm{pH} 3$ to 5 . Paclitaxel solutions at 0.1 and $1 \mathrm{mg} / \mathrm{cm}^{3}$ in $5 \%$ dextrose injection or $0.9 \%$ sodium chloride injection remained active for at least three days at 4,22 , or $32^{\circ} \mathrm{C}[15]$.

\section{Paclitaxel procedures of isolation from natural sources}

The first step involves washing raw plant material using deionized water [16]. The temperature of water is in the range of 20 to $25^{\circ} \mathrm{C}$, and duration of the process is $3 \mathrm{~h}$. Then, the water is removed along with all water soluble impurities. The second step is extraction with an organic solvent. The adequate solvents for this extraction are alcohols (methanol), ketones (acetone) and their mixtures. In cases where a mixture is used, the volume ratio in the mixture is about $1: 1$. The obtained extract is filtered to remove deposits, and then transferred to a double walled tank, where the water temperature is in the range of $65-70^{\circ} \mathrm{C}$. The organic solvent is then removed by distillation. The remaining solution is drained into another tank. Because there is residual water, that solution is a non-concentrated extract. The third step is isolation

Table 1. General characteristics of paclitaxel

\begin{tabular}{|c|c|}
\hline CAS number & $33069-62-4$ \\
\hline Molecular mass & 853.9 \\
\hline Molecular formula & $\mathrm{C} 47 \mathrm{H} 51 \mathrm{NO} 14$ \\
\hline Solubility information & $\begin{array}{l}\text { DMSO, methanol, ethanol. Unstable in } \\
\text { Methanol. }\end{array}$ \\
\hline Consistency & White crystalline solid. \\
\hline$\lambda \max$ & $227,273 \mathrm{~nm}$ \\
\hline Melting point & (decomposition) $200-220^{\circ} \mathrm{C}$ \\
\hline Solubility & $\begin{array}{l}\text { Clear colorless solution at } 10 \mathrm{mg} \cdot \mathrm{cm}-3 \text { of } \\
\text { methanol. } \\
\text { Solubility in water is } \sim 0,4 \mu \mathrm{g} \cdot \mathrm{cm}-3 \text {. }\end{array}$ \\
\hline $\begin{array}{l}\text { Specific optical } \\
\text { rotation }\end{array}$ & $-49 \sim-55$ \\
\hline Storage & $-20^{\circ} \mathrm{C}$. Protect from light. \\
\hline Warnings & $\begin{array}{c}\text { Warning! May cause birth defects. Irritates } \\
\text { eyes, skin, respiratory system }\end{array}$ \\
\hline Classification & $\begin{array}{c}\text { cyclodecane } \\
\text { Antitumor agent }\end{array}$ \\
\hline
\end{tabular}


of biomass from the solution obtained in the previous step. The extract is diluted in methanol and water and then salted out to precipitate the biomass. Sodium chloride is quickly added to the extract under heavy stirring. The formed biomass is separated from the solution by filtration or by centrifugation. The separated biomass, which is wet, can be dried by ventilation or lyophilization. The fourth step removes the resin and natural pigments by treating the dried biomass with mixture of acetone and hexane. An even better procedure is to put the dried biomass back into solution by first adding the mixture of acetone and hexane and adding 1.5 additional volumes of pure hexane. The final ratio of acetone and hexane is $1: 4$. Then, pure water is added to the obtained solution to form a paclitaxel-enriched oily phase, which is then transferred into decanting desk. The oily phase at the bottom of the flask contains paclitaxel and other taxanes. The fifth and final step is chromatographic purification of a solution of the paclitaxel-enriched oily phase and crystallizing the purified solution obtained by chromatography at least once. In this procedure, the paclitaxel-enriched oily phase is first mixed with silica gel and dried under ventilation. The silica gel coated with the oily phase is loaded onto a chromatographic column containing the same type of gel. The purification is conducted using the mixture comprising $35 \%$ of acetone and about $65 \%$ hexane. The fractions containing paclitaxel obtained by chromatography in the preceding step are evaporated to dryness and put back in an acetone solution. Then, the paclitaxel is crystallized by adding from 3 to 4 volumes of hexane to the acetone solution.

One published procedures uses acetone as an appropriate solvent for isolation of paclitaxel from plant material [17]. Acetone/water precipitation gives a very pure paclitaxel, which is useful for industrial scale isolation and normal-phase silica chromatography.

Accelerated solvent extraction (ASE) has been investigated under different conditions for isolation of paclitaxel and related analogue compounds from the bark of Taxus cuspidata (Japanese yew) [18]. This method uses more pressure in the cells to keep the solvent warm during the extraction. In this procedure, the time of extraction is shorter and the amount of desired product is higher. The conditions under which the obtained yield of paclitaxel is the highest are the following: solvent, $\mathrm{MeOH}: \mathrm{H}_{2} \mathrm{O}(90: 10 \mathrm{v} / \mathrm{v})$; temperature, $150^{\circ} \mathrm{C}$; and pressure, $10.13 \mathrm{MPa}$ (the yield after drying the sample was $0.128 \% \mathrm{~m} / \mathrm{m}$ ). ASE does not require a chlorinated solvent. It reduces the use of solvent, because of higher dissolving power. The obtained amount of paclitaxel and related compounds during ASE is higher even when water is used as the solvent as compared the yield from other methods.
A simple and efficient procedure of extraction was developed and optimized using enzymes to obtain of paclitaxel and the related compounds 7-xyl-10-deacetylpaclitaxel, 10-deacetylpaclitaxel, cephalomannine and 7-epi-10-deaceylpaclitaxel from needles of Taxus chinensis [19]. The optimal procedure of extraction begins with treatment with a cellulose solution of $1 \mathrm{mg} \cdot \mathrm{dm}^{-3}$, a liquid to solid ratio $1: 10\left(\mathrm{~cm}^{3} / \mathrm{g}\right)$, and incubation at $\mathrm{pH}$ 4 and $40^{\circ} \mathrm{C}$ for $24 \mathrm{~h}$. Under these optimal conditions, the yields of paclitaxel, 7-xyl-10-deacetylpaclitaxel, 10-deacetylpaclitaxel, cephalomannine and 7-epi10-deaceylpaclitaxel were 1.78, 1.26, 2.46, 3.01 and 2.25-times higher than in beta-glucosidase, respectively. Additionally, the influence of enzymes on the structural changes of the plant cells was observed by scanning electron microscopy (SEM). The extraction using enzymes was improved for ecologic and economic reasons for large-scale natural product extraction.

\section{Semi-synthesis of paclitaxel}

An initial substance for semi-synthesis of paclitaxel is 10-deacetylbaccatin-III (10-DAB), which can be isolated from needles and wattles of the European yew (Taxus baccata) [20]. There are two procedures for synthesis, both of which start with 7-O-TES-baccatin-III obtained by selective silylation and acetylation of 10-DAB [21]. In the first procedure developed and published in the patent literature by Holton [22], lithium ions are reacted with $\beta$-lactam to introduce a desirable amino acid chain at the 13-position. Bristol-Myers Squibb Co [23], and also [24] presented the second procedure for synthesis in the patent literature. 7-O-TES-baccatin-III was reacted with oxazolinecarboxylic acid ((4S-trans)-4,5-dihydro-2,4-diphenil-5-oxazolecarboxylic acid) using dicyclohexylcarbodiimide (DCC) or a similar dehydrating agent. A third synthetic procedure is based on coupling 7-O-Trocbaccatin-III with the protected $\beta$-phenylisoserine using DCC [25].

\section{Total synthesis of paclitaxel}

The structural elements of paclitaxel (Figure 1), in addition to the main $A, B$ and $C$ rings, include an oxetan ring (D-ring), an $\mathrm{N}$-benzoyphenylisoserine side chain appended to $\mathrm{C}-13$ of the $\mathrm{A}$ ring and the benzoate group at C-2 of the B ring [7]. Two groups of scientists [26,27] have published procedures of total synthesis of paclitaxel with low yields at $2.7 \%$ and $0.07 \%$, respectively. Nicolaou's group started first with construction of the A and $C$ rings separately and then coupling the two mol- 
ecules using a Shapiro and McMurry coupling to form the $B$ ring. Further reactions were carried out to produce the final product of paclitaxel. Holton et al. started with (-)-borneol, which they converted to an unsaturated ketone through 13 synthetic steps. Two years later, Danishefsky et al. published a third procedure, which had fewer steps than Holton's and Nicolaou's procedures [28]. The method used the Wieland-Miescher-ovim ketone as a starting material, which was then converted to a complex enol triflate containing an olefin on the $\mathrm{C}$ ring that allowed for the development of paclitaxel via an intramolecular Heck reaction. Morihira and coworkers have published yet another procedure for paclitaxel synthesis [29]. These procedures represent great achievements in the scientific community, but still cannot be used for industrial production, because in several synthetic steps the yields of intermediates are very low. Therefore, these total synthesis methods of paclitaxel production are too expensive and too complex.

\section{Complexes of paclitaxel}

Pharmaceutical substances are usually insoluble in water; therefore, increased solubility is important for a drug to be administered intravenously. Different types of carriers that increase solubility, such as cyclodextrins [30-32] oligosaccharides (dextrane, pullulan) [33,34], liposomes, and polymers, have been tested. These substances provide better absorption of the active substance during a treatment of a disorder. Coupling a bioactive compound to a biocompatible polymer offers, in general, many advantages, such as better drug solubilization, better stabilization, specific localization, and controlled release.

Cyclodextrins (CyD) are complexing agents that can increase the solubility and stability of poorly soluble active substances [35]. Studies have been done on the different types of $\beta$ - and $\gamma$ - CyDs. (Hydroxypropyl)-(HP $\beta-C y D)$, (hydroxyethyl)-(HE $\beta-C y D)$ and dimethyl-(DM $\beta-C y D) \beta-C y D$ belong to this group; they increase the solubility of paclitaxel by a factor of 2,000 without changing the cytostatic activity of paclitaxel in vitro. The amount of dissolved active substance increased with increasing cyclodextrin concentration. In some cases, the precipitation of cyclodextrins in solution was observed. Thermal and spectroscopic analyses (fluorescence, IR, NMR and circular dichroism) confirmed the formation of complexes, which were more stable in the solid form than in the solution. This can be explaine the occurrence of precipitate in the solution. DM $\beta-C y D$ solutions of $\leq 3.7 \mathrm{~mol} \%$ (mol paclitaxel/mol cyclodextrin) showed no precipitation upon dilution, nor did HP $\beta-$ CyD solutions of $\leq 0.14 \mathrm{~mol} \%$.
The solubility and bioactivity of inclusion complexes of paclitaxel using 11 different cyclodextrins, ( $\alpha-C y D$, $\beta-C y D, y-C y D$, mono-6-O-maltosyl $\alpha-C y D\left(G_{2}-\alpha-C y D\right)$, mono-6-O-maltosyl $\beta-C y D \quad\left(G_{2}-\beta-C y D\right)$, mono-6-Omaltosyl $\gamma-C y D\left(G_{2}-\gamma-C y D\right)$, heptakis-(2,6-di-O-methyl) $\alpha-C y D(D M-\alpha-C y D)$, heptakis-(2,6-di-O-methyl) $\beta-C y D$ (DM- $\beta-C y D)$, heptakis-(2,3,6-tri-O-methyl) $\beta-C y D$ (TM$\beta-C y D)$, hydroxyethyl $\beta-C y D$ (HE- $\beta-C y D)$, hydroxypropyl $\beta$-CyD (HP- $\beta-C y D)$ ), was studied by Hamada and coworkers [36]. From this group of cyclodextrins, 2,6-dimethyl $\beta-C y D$ was shown to be the most efficient, with the solubility of paclitaxel at $2.3 \mathrm{mmol} / \mathrm{dm}^{3}$ in a cyclodextrin solution of $0.1 \mathrm{mmol} / \mathrm{dm}^{3}$. This inclusion complex of paclitaxel has 1.23 times higher polymerization activity than paclitaxel in tubulin.

Today, the formulation on the basis of the inclusion complexes of cyclodextrin and paclitaxel is used [35], most commonly with a paclitaxel to cyclodextrin ratio of 1:10 to 1:150. Different types of cyclodextrins, such as hydroxypropyl-sulphobutyl-7- $\beta-C y D$, sulphobutylether7- $\beta$-CyD, $\quad$ acetyl- $-C y D, \quad$ hydroxypropyl- $\beta-C y D$, hydroxypropyl-y-CyD, bis( $\beta-C y D), \quad \gamma-C y D$, succinylmethyl- $\beta-C y D$, anionic- $\beta-C y D$, as well as their mixtures, can be used for making these formulations. The stability constant of these inclusion complexes lie in the range $\mathrm{K}_{\mathrm{a}}=5.396-1.412 \mathrm{dm}^{3} / \mathrm{mol}$. Preparing the formulations is done in the following manner: (a) the solution of cyclodextrin is added dropwise to the ethanol solution of paclitaxel. (b) After the paclitaxel dissolves, the obtained mixture is filtered through a microporous membrane $(0.2-0.4 \mu \mathrm{m})(\mathrm{c})$ Then, ethanol is removed at low pressure, giving a liquid inclusion that contains less than $2 \%$ ethanol. The residual water is also removed in the same way. Paclitaxel $\left(20 \mathrm{mg} / \mathrm{cm}^{3}\right)$ remains more active in cyclodextrin solutions $(10 \%-20 \%)$ than in buffer solutions of comparable $\mathrm{pH}$ [37]: There was less than $1 \%$ decomposition of paclitaxel in the cyclodextrin solutions stored for one month at $37^{\circ} \mathrm{C}$.

The incorporation of paclitaxel into hydrotropic polymeric micelles, with a shell of poly(ethylene glycol) (PEG), and a core of poly(2-(4-vinylbenzyloxy)-N,N-diethylnicotinamide) (P(VBODENA), has been described [38]. This procedure improved the solubility and stability of paclitaxel. To study the stability, a control was used in which paclitaxel was incorporated in polymeric micelles of poly(ethylene glycol)- $b-\mathrm{P}(\mathrm{D}, \mathrm{L}-$-lactide) (PEG- $b$-PLA). The maximal amount of paclitaxel incorporated in the micelles of PEG- $b$-P(VBODENA) was higher than 37.4 mass $\%$, compared with the 27.6 mass $\%$ in the micelles of PEG- $b$-PLA. Above 30 mass $\%$ of paclitaxel was located inside polymeric micelles in a molecularly dispersed amorphous state, as confirmed by thermal analysis. Hydrotropic polymer micelles can remain stable for a few 
weeks, while micelles of PEG- $b$-PLA precipitate after a few days. Hydrotropic polymer micelles are also more efficient than PEG-PLA micelle formulations in inhibiting the proliferation of human cancer cells. Paclitaxel in the form of hydrotropic polymer micelles has been administered to rats orally $(3.8 \mathrm{mg} / \mathrm{kg})$, intravenously $(2.5 \mathrm{mg} /$ $\mathrm{kg})$, or through the portal vein $(2.5 \mathrm{mg} / \mathrm{kg})$. The results of research showed that the polymer micelles with a hydrotropic structure were the better carriers, because of their high solubility and long-term stability.

Paclitaxel-loaded poly( $\varepsilon$-caprolactone)(PCL)/pluronic F68 (F68) nanoparticles were spherical with a porous surface [39]. F68 was incorporated in the matrix of PCL. These substances are usually used as an agent for formation of pores. Paclitaxel-loaded PCL/F68 nanoparticles were shown to be more efficient than conventional injections of paclitaxel. Therefore, paclitaxel-loaded PCL/F68 nanoparticles can effectively prevent tumor cell growth. These data suggest an eventual possible use of this preparation for treatment of breast cancer.

Nanoparticles were formulated with pluronic F-68 and liquid PEG (Mr 400) using a rapid, simple, and continuous procedure without presence of solvents [40]. Paclitaxel was contained in these nanoparticles (Figure 2). The liquid PEG was used as a solubilizer of paclitaxel. A liquid polymer mixture was formulated from the emulsion of PEG, paclitaxel and pluronic F-68. On a nanometer scale, $\mathrm{PEG} /$ paclitaxel was incorporated in pluronic $\mathrm{F}-68$ by cooling at $0^{\circ} \mathrm{C}$ until the appearance of pluronic nanoparticles. The morphology and size of the pluronic nanoparticles formed can be observed using FE-SEM and TEM. These studies were done on tumor mice to investigate a use of pluronic nanoparticles as a system for controlled release of active substance in tumor treatment. Also, the time-dependent excretion profile, in vivo biodistribution, and circulation time was evaluated. The paclitaxel-loaded was rapidly released in the first $7 \mathrm{~h}$. Up to $48 \mathrm{~h}$, the paclitaxel release remained constant. The paclitaxel-loaded pluronic nanoparticles were more efficient compared with paclitaxel formulated in Cremophor EL.

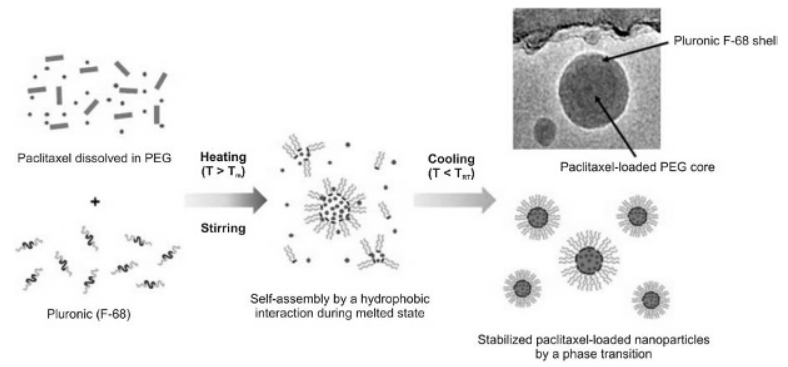

Figure 2. Procedure for making nanoarticles of paclitaxel with pluronic F-68 and liquid PEG
Phospholipids in combination with aqueous solvent or hydrophilic polymers, as PEG, were used as a matrix for incorporation of paclitaxel molecules [41]. The particles formed had an average size of $1000 \mathrm{~nm}$. Conjugates on the basis of linear biodegradable copolymers of $\mathrm{N}$-(2-hydroxypropyl) methacroylamide (HPMA) and units of methacryloylated hydrazones of amino acids and oligopeptides with paclitaxel have been described in the literature [42]. The research was also moved in the direction of obtaining a polymer analog. Hyaluronicpaclitaxel hydrosoluble bioconjugates appear promising as cancer therapy. Their cytotoxicity against various cancer cell lines is, in fact, comparable to that of free paclitaxel, and the systemic toxicity is reduced owing to selective targeting of cancer cells [43].

Application of paclitaxel in the form of intravenous infusion required lecithin as a carrier [44]. A paclitaxel concentration of $1 \mathrm{mg} / \mathrm{cm}^{3}$ was achieved in $24 \mathrm{~h}$ by making micelles. Aqueous dispersions of egg or soya lecithin (water-lecithin dispersion, WLD), and mixed micellar (MM) solutions of lecithin from egg and sodium deoxycholate were investigated. Also, a new formulation with lecithin, co-surfactants and co-solvents poloxamer, polysorbate, Span, benzalkonium chloride, and macrogol were developed. The amorphous paclitaxel was prepared by lyophilization. Unlike crystalline paclitaxel, the drug in an amorphous form is easily soluble in a $1 \%$ to $5 \%(\mathrm{w} / \mathrm{w})$ WLD or MM. The highest solubility (up to $5.70 \mathrm{mg} / \mathrm{cm}^{3}$ ) was achieved in 5\% WLD. Dissolved paclitaxel precipitated in all investigated formulations after $24 \mathrm{~h}$. Otherwise, paclitaxel concentration of $1 \mathrm{mg} \cdot \mathrm{cm}^{-3}$ after $24 \mathrm{~h}$ in $5 \%$ egg WLD, $1 \%$ to $5 \%$ soya WLD, and in 5\% MM (lecithin : deoxycholate ratio $1: 1 \mathrm{w} / \mathrm{w}$ ). After $24 \mathrm{~h}$, precipitation of paclitaxel was not noted for different batches of $5 \%$ WLD. That formulation was adequate for further in vivo studies. The solubility of paclitaxel in lecithin is not increased by addition of surfactants and co-lyophilization.

\section{Methods for isolation and purifica- tion of paclitaxel from plant materials}

Paclitaxel was isolated from a crude plant extract by normal phase chromatography [45]. Polyamide was used as the stationary phase, with a mixture of dialkyl ketone and weakly polar solvent as the mobile phase. Acetone and methyl isobutyl ketone are dialkyl ketones, while $\left(\mathrm{C}_{5}-\mathrm{C}_{8}\right)$ aliphatic hydrocarbons, $\left(\mathrm{C}_{6}-\mathrm{C}_{8}\right)$ aromatic hydrogencarbons, $\left(\mathrm{C}_{1}-\mathrm{C}_{4}\right)$ dialkyl ether to weakly polar co-solvents. The otained chromatogram at exposed conditions is shown as Figure 3. 


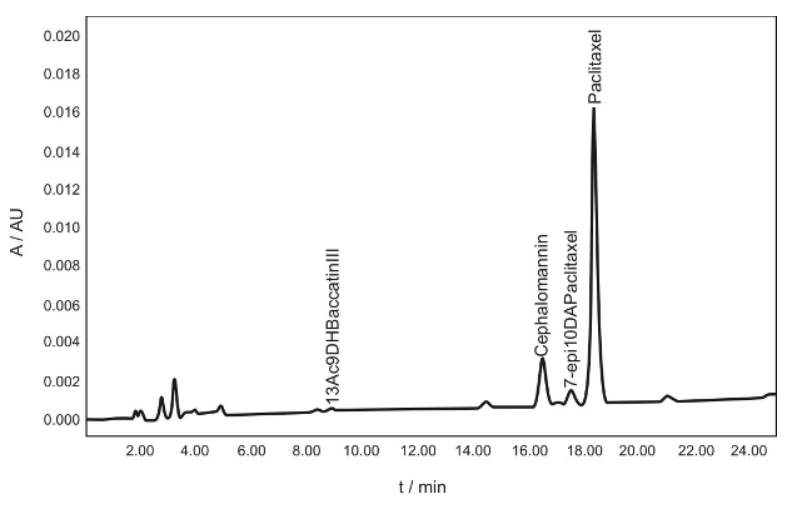

Figure 3. Chromatogram of crude plant extract

An improved method for separation of paclitaxel and its analogs from Taxus species includes treating the extract by reverse-phase liquid chromatography on the adsorbent [46]. First, paclitaxel and its analogs are adsorbed on the adsorbent and then eluted. The compounds, which are isolated in pure form, are paclitaxel, paclitaxel7-xyloside, 10-deacetylpaclitaxel, 10-deacetylpaclitaxel7-xyloside, cephalomannine, cephalomannine-7-xyloside, 10-deacetylcephalomannine-7-xyloside, baccatin III, 10-deacetylbaccatin III, baccatin VI, brevitaxane A and taxiflorine. The simple and efficient procedure for isolation of paclitaxel from the bark of Taxus brevifolia is described in literature [47]; this method uses a reverse phase $\mathrm{C}_{18}$ column.

\section{Paclitaxel mechanism of action}

Paclitaxel is a complex diterpene with antitumor activity against ovarian, breast, lung, and prostate cancer $[14,48]$, and acts as a promoter of tubulin polymerization and stabilizes microtubules to depolymerization by different agents, both in vitro and in vivo $[49,50]$. Paclitaxel alters the normal equilibrium between tubulin dimmers and microtubules, and, therefore, disrupts cell division [51]. The paclitaxel-stabilized microtubules are resistant to depolymerization upon exposure to calcium ions and cold temperatures, and do not require the presence of guanosine triphosphate (GTP) [14,50]. Unlike other spindle poisons, which prevent polymerization of the monomer, paclitaxel has a binding site on the microtubule [14].

The proposed mechanism of action, metabolism, relationship between structure and activity, such as pharmacokinetics of paclitaxel, have been explained in the literature [14,49,52-58]. Analogs of paclitaxel having good biological activity have been synthesized $[14,48,51,52,57,59,60]$.
Paclitaxel in concentrations as low as $0.05 \mu \mathrm{mol} /$ $\mathrm{dm}^{3}$ promoted microtubule assembly in vitro, even in the absence of GTP or microtubule-associated proteins (MAPs) [61]. Studies of HeLa cells and fibroblasts treated with paclitaxel $\left(0.25\right.$ or $\left.10 \mu \mathrm{mol} / \mathrm{dm}^{3}\right)$ show that paclitaxel blocks cells in the $\mathrm{G} 2$ and M phase of the cell cycle [62]. More than $90 \%$ of the cells treated with 10 $\mu \mathrm{mo} 1 / \mathrm{dm}^{3}$ taxol for $22 \mathrm{~h}$ at $37^{\circ} \mathrm{C}$ displayed bundles of microtubules that appeared to radiate from a common site (or sites), in addition to their cytoplasmic microtubules. Untreated cells that were kept in the cold $\left(4^{\circ} \mathrm{C}\right)$ for $16 \mathrm{~h}$ lost their microtubules, whereas cells that were pretreated with taxol for $22 \mathrm{~h}$ at $37^{\circ} \mathrm{C}$ continued to display their microtubules and bundles of microtubules in the cold. HeLa (human) cells, strain S3, were grown in suspension culture in Joklik's modified Eagle's minimal essential medium supplemented with $5 \%$ fetal calf serum and $1 \%$ glutamine. A primary cell line of male BALB/C mouse fibroblasts (provided by Susie Chen) and Swiss 3T3 mouse fibroblasts were grown as monolayers in Dulbecco's modified Eagle's medium supplemented with $10 \%$ fetal calf serum. Fibroblast cells used in the experiments were no older than 20 passages.

In nonmalignant cells, paclitaxel inhibits specific functions such as chemotaxis, migration, and cell spreading. It inhibits the slow transportation of tubulin, actin, and polypeptides in axons [52] and the proliferation of stimulated lymphocytes, decreased tumor necrosis factor- $\alpha$ (TNF- $\alpha$ ) receptors, induced (at $1-30 \mathrm{mmol} /$ $\mathrm{dm}^{3}$ ) murine macrophages to express TNF- $\alpha$ mRNA and genes associated with the LPS-induced macrophage activation, and induces protein tyrosine phosphorylation [52,53,63,64]. Paclitaxel inhibits secretory functions of specialized cells, catecholamine from adrenal medullar cells, plasma proteins from rat liver cells, and prothrombinase from platelets [52].

\section{The side effects of paclitaxel}

Common side effects include nausea and vomiting, loss of appetite, change in taste, thinned or brittle hair, pain in the joints of the arms or legs lasting two to three days, changes in the color of the nails, and tingling in the hands or toes [65]. More serious side effects such as unusual bruising or bleeding, change in normal bowel habits for more than two days, fever, chills, cough, sore throat, difficulty swallowing, dizziness, shortness of breath, severe exhaustion, skin rash, facial flushing, female infertility by ovarian damage, and chest pain can also occur. A number of these side effects are the results of other excipients in the applied preparation. 


\section{Methods for monitoring of pacli- taxel concentration}

For monitoring paclitaxel in parenteral dosage forms, a validated RP-HPLC method was used [66], and is adequate for routine determination in pharmaceutical dosage form. Separation of the analyzed samples was done on US $\mathrm{C}_{18}$ column, where the mobile phase is a methanol and aqueous solution of potassium dihydrogen phosphate of $0.02 \mathrm{~mol} / \mathrm{dm}^{3}$ ratio $80: 20 \mathrm{v} / \mathrm{v}(\mathrm{pH}$ of 2.5 was adjusted with phosphoric acid). The flow rate was 1 $\mathrm{cm}^{3} / \mathrm{min}^{1}$, and wavelength, $225 \mathrm{~nm}$. Retention time of paclitaxel was $4.978 \mathrm{~min}$ under these conditions. The detector response was linear in the range $15-180 \mu \mathrm{g} / \mathrm{cm}^{3}$.

There is also a sensitive, specific, and reproducible HPLC method for quantitative determination of paclitaxel in plasma, tissue and tumor mice. Samples of liver, kidney, spleen, lung, heart, and tumor tissues were separately homogenized in bovine serum albumin (BSA, $40 \mathrm{~g} / \mathrm{dm}^{3}$. Homogenates of plasma or tissue $(0.1$ $\mathrm{cm}^{3}$ ), containing paclitaxel and inter standard (dimethyl4,4'-dimethoxy-5,6,5',6'-dimethilen dioxy biphenyl-2,2' dicarboxilate), were extracted with ethyl acetate (10 $\mathrm{cm}^{3}$ ). An ODS column was used for separation of components from the biological samples. The samples were recorded at $227 \mathrm{~nm}$. A gradient system containing acetonitrile and deionized water was used for quantification of paclitaxel. This HPLC method has been successfully used for determination of paclitaxel for pharmacokinetic and biodistribution studies.

Monitoring of paclitaxel concentration and verapamil in rats blood plasma is possible using a HPLC method with isocratic mode and UV detection [67]. First, the plasma samples were exposed to one-step liquid-liquid extraction by terc-buthyl methyl ether. Paclitaxel, verapamil and n-buthyl p-hydroxy benzoate, as inter standard, were separated very well on an ODS column. As the mobile phase, this method used a mixture of ammonium acetate buffer $\left(50 \mathrm{mmol} / \mathrm{dm}^{3}, \mathrm{pH} 6.0\right)$ and acetonitrile $(54: 46, v / v)$. Another HPLC method has been applied for rapid and simple determination of paclitaxel, without prior sample preparation, in the presence of polyoxyl castor oil [68].

To lower the administered doses of paclitaxel to reduce its side effects, the ability to measure lower concentrations of paclitaxel is important. Baldery et al. have developed two methods, one using HPLC-UV and the other, LC-MS-MS [69]. In the HPLC-UV method, devel- oped to analyze the paclitaxel in dog toxicokinetic studies, paclitaxel was extracted from human plasma by a simple solid phase extraction on cyano cartridges. For analysis, the volume of plasma between 0.5 and $1.0 \mathrm{~cm}^{3}$ is necessary, which can sometimes be a problem for toxicology studies in small animals. The compound was eluted from the cartridges with a mixture of acetonitrile and triethylamine $(1000: 1, \mathrm{v} / \mathrm{v})$. The eluate was evaporated and the compound was dissolved in the mobile phase; the sample was then injected onto an Apex-Octyl column $(150 \times 4.6 \mathrm{~mm})$. The mobile phase of acetonitrile: methanol : ammonium acetate $\left(0.02 \mathrm{~mol} / \mathrm{dm}^{3}, \mathrm{pH} 5\right)$ in a proportion of $4: 1: 5(\mathrm{v} / \mathrm{v} / \mathrm{v})$ was run at $1 \mathrm{~cm}^{3} / \mathrm{min}$. The samples were detected at $227 \mathrm{~nm}$.

The LC-MS-MS method used human plasma (0.1 $\mathrm{cm}^{3}$ ). The cleanup of the samples was performed by an L-L extraction using diethyl ether to extract paclitaxel from plasma at $\mathrm{pH} 4$ (by addition of ammonium acetate). The sample tubes were rotary mixed and centrifuged. The organic layer was transferred and blown to dryness. The compound was dissolved in a mobile phase and then injected onto a Hypersil $C_{1}$ column $(100 \times 2.1 \mathrm{~mm})$. The mobile phase was mixture of acetonitrile and aqueous formic acid $(0.1 \%, v / v)$ in a proportion $1: 1(\mathrm{v} / \mathrm{v})$.

\section{Conclusion}

Paclitaxel, as anticancer drug, can be isolated from Taxus species. It occurs as a metabolite of a special fungus. The microbiological route characteristically involves a shorter time for paclitaxel production compared with synthetic procedures. Its main disadvantage is a low yield of the bioactive substance. In medicine, paclitaxel is usually used for treatment of ovarian, breast, lung, and prostate cancer. Different types of carriers are used to improving its solubility and stability. Analytical methods have been developed and validated for monitoring the paclitaxel content in pharmaceutical formulation.

\section{Acknowledgments}

This work was supported by the Ministry of Education and Science of the Republic of Serbia under the project TR-34012. Ivan Savic is a recipient of a scholarship granted by the Ministry of Education and Science of the Republic of Serbia. 


\section{References}

[1] Rowinsky E.K., Donehower R.C., Paclitaxel (taxol). N. Engl. J. Med., 1995, 332, 1004-1014

[2] Wani M.C., Taylor H.L., Wall M.E., Coggan P., McPhail A.T., Plant antitumor agents. VI. The isolation and structure of taxol, a novel antileukemic and antitumor agent from Taxus brevifolia, J. Am. Chem. Soc., 1971, 93, 2325-2327

[3] Schiff PB, Fant J, Horwitz SB; Promotion of microtubule assembly in vitro by taxol. Nature 1979;(227):665-667

[4] Schiff P.B., Horwitz S.B., Taxol stabilizes microtubules in mouse fibroblast cells, PNAS 1980, 77, 1561-1565

[5] Rowinsky E.K., Cazenave L.A., Donehower R.C., Taxol: a novel investigational antimicrotubule agent, J. Natl. Cancer I 1990, 82, 1247-1259

[6] Stierle A., Strobel G., Stierle D., Taxol and taxane production by Taxomyces andreanae, an endophytic fungus of pacific yew, Science 1993, 260, 214216

[7] Guo B.H., Kai G.Y., Jin H.B., Tang K.X., Taxol synthesis. Afr. J. Biotechnol. 2006, 5(1), 15-20

[8] Strobel G., Yang X.S., Sears J., Kramer R., Sidhu R.S., Hess W.M., Taxol from Pestalotiopsis microspora, an endophytic fungus of Taxus wallachiana, Microbiology 1996, 142, 435-440

[9] Li J.Y., Stroble G., Sidhu R., Hess W.M., Ford E.J., Endophytic Taxolproducing fungi from bald cypress. Taxodium distichum, Microbiology 1996, 142, 22232226

[10] Wang J.F., Li G.L., Lu H.Y., Zheng Z.H., Huang Y.J., Su W.J., Taxol from Tubercularia sp. strain TF5, an endophytic fungus of Taxus mairei, FEMS Microbiol. Lett. 2000, 193, 249-253

[11] U. Breme, M. Caruso, N.C. Perellino, L. Fedeli, A. Pavesi, L. Piacenza, G. Ventrella, 2003. Paclitaxel production by Actinomycetes. U.S. patent $6,528,301$

[12] Adler L.M., Herzog T.J., Williams S., Rader J.S., Mutch D.G., Analysis of exposure times and dose escalation of paclitaxel in ovarian cancer cell lines, Cancer 1994, 74, 1891-1898

[13] Richheimer S.L., Tinnermeier D.M., Timmons D.W., High-performance liquid chromatographic assay of taxol, Anal. Chem. 1992, 64(20), 2323-2326.

[14] Vyas D.M., Kadow J.F., Paclitaxel: A Unique Tubulin Interacting Anticancer Agent, Progr. Med. Chem. 1995, 32, 289-337
[15] Xu Q., Trissel L.A., Martinez J.F., Stability of paclitaxel in $5 \%$ dextrose injection or $0.9 \%$ sodium chloride injection at 4,22 , or $32^{\circ} \mathrm{C}, \mathrm{Am}$. J. Hosp. Pharm. 1994, 51, 3058-3060

[16] T.B. Khac, M. Potier, 2004. Process for isolation and purification of paclitaxel from natural sources. U.S. patent 6,759,539

[17] S.S.K. Foo, Y. Bai, M. Ehlert, 2000. Method for high yield and large scale extraction of paclitaxel from paclitaxel-containing material. U.S. patent $6,136,989$

[18] Kawamura F, Kikuchi Y, Ohira T, Yatagai M. Accelerated Solvent Extraction of Paclitaxel and Related Compounds from the Bark of Taxus cuspidate. J. Nat. Prod. 1999, 62(2), 244-247

[19] Zu Y., Wang Y., Fu Y., Li S., Sun R., Liu W., Luo H., Enzyme-assisted extraction of paclitaxel and related taxanes from needles of Taxus chinensis, Sep. Purif. Technol. 2009, 68(2), 238-243

[20] P. Vemishetti, F.S. Gibson, J.L. Dillon, 2001. Semisynthesis of paclitaxel using dialkyildichlorosilanes. U.S. patent 6,242,614 B1

[21] Denis J.N., Greene A.E., Guenard D., Voegelein F.G., Potier L.M.P., Highly efficient, practical approach to natural taxol, J. Am. Chem. Soc. 1988, 110(17), 5917-5919

[22] R.A. Holton, 1993. Metal alkoxides. U.S. patent $5,274,124$

[23] M.A. Poss, J.L. Moniot, I.D. Trifunovich, D.J. Kucera, J.K. Thottathil, S.H. Chen, J. Wei, 1994. Novel sidechain-bearing taxanes and intermediates thereof. W.O. patent 9414787

[24] Kingston D.G.I., Chaudhary A.G., Gunatilaka A.A.L., Middleton M.L., Tetrahedron. Lett. 1994, 35, 4483-4484

[25] Commerçon A., Bézard D., Bernard F., Bourzat J.D., Improved protection and esterification of a precursor of the taxotere $\AA$ and taxol side chains, Tetrahedron. Lett. 1992, 33(36), 5185-5188

[26] Holton R.A., Somoza C., Kim H.B., Liang F., Biediger R.J., Boatman P.D., Shindo M., Smith C.C., Kim S., Nadizadeh H., Suzuki Y., Tao C., Yu P., Tang S., Zhang P., Murthi K.K., Gentile L.N., Liu J.H., First total synthesis of Taxol, J. Am. Chem. Soc. 1994, 116, 1597-1600

[27] Nicolaou K.C., Yang Z., Liu J.J., Ueno H., Nantermet P.G., Guy R.K., Claiborne C.F., Renaud J., Couladouros E.A., Paulvannan K., Sorensen E.J., Total synthesis of Taxol, Nature 1994, 367, 630-634 
[28] Danishefsky S.J., Master J.J., Young W.B., Link J.T., Snyder L.B., Magee T.V., Jung D.K., Isaacs R.C.A., Bornmann W.G., Alaimo C.A., Coburn C.A., Di Grandi M.J., Total Synthesis of Baccatin III and Taxol, J. Am. Chem. Soc. 1996, 118, 2843-2859

[29] Morihira K., Hara R., Kawahara S., Nishimori T., Nakamura N., Kusama H., Kuwajima I., Enantio-selective total synthesis of Taxol, J. Am. Chem. Soc. 1998, 120, 12980-12981

[30] Nikolic V., Stankovic M., Kapor A., Nikolic Lj., Cvetkovic D., Stamenkovic J., Allylthiosulfinate: $\beta$ Cyclodextrin Inclusion Complex: Preparation, Characterization and Microbiological Activity, Die Pharmazie 2004, 59(11), 845 - 848

[31] Nikolic V., Nikolic Lj., Stankovic M., Kapor A., Popsavin M., Cvetkovic D., A molecular inclusion complex of atenolol with 2-hydroxypropyl- $\beta$-cyclodextrin; production and characterization thereof, J. Serb. Chem.Soc. 2007, 72(8-9), 737 - 746

[32] Nikolic V., Ilic D., Nikolic Lj., Stankovic M., Cakic M, Stanojevic Lj., Kapor A., Popsavin M., The protection of Nifedipin from photodegradation due to complex formation with $\beta$-cyclodextrin, Cent. Eur. J. Chem. 2010, 8(4), $744-749$

[33] Savic I., Nikolic G., Savic I., Cakic M., Studies of the forced hydrolysis degradation of copper complexes with different oligosaccharides, Russ. J. Phys. Chem. A 2010, 84(13), 2306-2313

[34] Savic I., Nikolic G., Savic I., Cakic M., Conductometric studies on the stability of copper complexes with different oligosaccharides, Cent. Eur. J. Chem. 2010, 8(5), 1078-1085

[35] Sharma U.S., Balasubramanian S.V., Straubinger R.M., Pharmaceutical and physical properties of paclitaxel (Taxol) complexes with cyclodextrins, J. Pharm. Sci. 1995,84(10), 1223-1230

[36] Hamada H., Ishihara K., Masuoka N., Mikuni K., Nakajima N., Enhancement of Water-Solubility and Bioactivity of Paclitaxel using Modified Cyclodextrins, J. Biosci. Bioeng. 2006, 102(4), 369-371

[37] Dordunoo S.K., Burt H.M., Solubility and stability of paclitaxel: effects of buffers and cyclodextrins, Int. J. Pharm. 1996, 133, 191-201

[38] R.Yong, G. Jianfeng, Y. Shuqin, W. Ling, 2009. Pharmaceutical composition comprising cyclodextrin paclitaxel inclusion and preparation method thereof. Eu patent 075010

[39] Lee S.C., Huh K.M., Lee J., Cho Y.W., Galinsky R.E., Park K., Hydrotropic Polymeric Micelles for Enhanced Paclitaxel Solubility: In Vitro and In Vivo Characterization, Biomacromolecules 2007, 8(1), 202-208
[40] Ma G., Yang J., Zhang L., Song C., Effective antitumor activity of paclitaxel-loaded poly ( $\varepsilon$-caprolactone)/pluronic F68 nanoparticles after intratumoral delivery into the murine breast cancer model, Anti-cancer drugs 2010, 21(3), 261-269

[41] Oh K.S., Song J.Y., Cho S.H., Lee B.S., Kim S.Y., Kim K., Jeon H., Kwon I.C., Yuk S.H., Paclitaxel-loaded Pluronic nanoparticles formed by a temperature-induced phase transition for cancer therapy, J. Control. Releas. 2010; doi:10.1016/j. jconrel.2010.08.021

[42] C. Mahesh, W. Jane, R.E. Barrett, 2005. Method for preparing submicron particles of paclitaxel. W.O. patent 0466712005

[43] Tomas E., Karel U., Blanka R., Milada S., Design, Synthesis and Applications of Hyaluronic Acid-Paclitaxel Bioconjugates, Molecules 2008, 13, 360378

[44] Leonelli F., Bella A.L., Migneco L.M., Bettolo R.M., Design, Synthesis and Applications of Hyaluronic Acid-Paclitaxel Bioconjugates, Molecules 2008, 13, 360-378

[45] B. Martin, C. Ladisav, S. Roman, S. Pavel, 2006. Process for the isolation of paclitaxel. W.O. patent 014356

[46] K.V. Rao, 1995. Method for the isolation and purification of taxol and its natural analogues. U.S. patent $5,475,120$

[47] Rao K.V., Taxol and related taxanes. I. Taxanes of Taxus brevifolia bark, Pharm. Res. 1993, 10(4), 521-524

[48] Wall M.E., Wani M.C., Camptothecin and Taxol: Discovery to Clinic-Thirteenth Bruce F. Cain Memorial Award Lecture, Cancer Rese. 1995, 55, 753-760

[49] Carlier M.F., Pantaloni D., Taxol Effect on Tubulin Polymerization and Associated Guanosinev 5'-Triphosphate Hydrolysis, Biochemistry 1983, 22, 4814-4822

[50] Schiff P.B., Fant J., Horwitz S.B., Promotion of microtubule assembly in vitro by taxol, Nature 1979, 277(5698), 665-667

[51] Georg G.I., Boge T.C., Cheruvallath Z.S., Clowers S.J., Harriman G.C.B., Hepperle M., Park H., The medical chemistry of taxol. In: Suffness M (ed.), Taxol science and applications. , Boca Raton: CRC Press, 1995, pp. 317-375

[52] Nicolaou K.C., Dai W.M., Guy R.K., Chemistry and biology of taxol, Angew. Chem. Int. Edit. 1994, 33, 15-44 
[53] Han Y., Chaudhary A.G., Chordia M.D., Sackett D.L., Ramirez B.P., Kingston D.G.I., Bane S., Interaction of a Fluorescent Derivative of Paclitaxel (Taxol) with Microtubules and Tubulin-Colchicine, Biochemistry 1996, 35, 14173-14183

[54] Horwitz S.B., Mechanizam of action of Taxol, Trends Pharmacol. Sci. 1992, 13(4), 134-136

[55] Suffness M., Taxol: From Discovery to Therapeutic Use, Ann. Rep. Med. Chem. 1993, 28, 305-314

[56] Horwitz S.B., Cohen D., Rao S., Ringel I., Shen H.J., Yang C.P., Taxol: mechanisms of action and resistance, J. Nati. Cancer I 1993, 15, 55-61

[57] Kingston D.G.I., Taxane Anticancer Agents, Chapter 15. USA: American Chemical Society, 1995

[58] Rowinsky E.K., Cazenave L.A., Donehower R.C., Taxol: a novel investigational antimicrotubule agent, J. Nati. Cancer I 1990, 82(15), 1247-1259

[59] Kant J., The Chemistry and Pharmacology of Taxol and Its Derivatives, 5 ed. New York, Pharmochemistry Library, Elsevier, 1995

[60] Boge T.C., Himes R.H., Velde D.G.V., Georg G.I., The effect of the aromatic rings of taxol on biological activity and solution conformation: synthesis and evaluation of saturated taxol and taxotere analogues, J. Med. Chem. 1994, 37(20), 3337-3343

[61] Rowinsky E.K., Donehower R.C., The clinical pharmacology and use of antimicrotubule agents in cancer chemotherapeutics, Pharmacol. Therapeut. 1991, 52(1), 35-84

[62] Schiff P.B., Horwitz S.B., Taxol stabilizes microtubules in mouse fibroblast cells, PNAS 1980, 77(3), 1561-1565
[63] Ding A.H., Porteu F., Sanchez E., Nathan C.F., Shared actions of endotoxin and taxol on TNF receptors and TNF release, Science 1990, 248(4953), 370-372

[64] Manthey C.L., Brandes M.E., Perera P.Y., Vogel S.N., Taxol increases steady-state levels of lipopolysaccharide-inducible genes and protein-tyrosine phosphorylation in murine macrophages, J. Immunol. 1992, 149(7), 2459-2465

[65] Ozcelik B., Turkyilmaz C., Ozgun M.T., Serin I.S., Batukan C., Ozdamar S., Ozturk A. Prevention of paclitaxel and cisplatin induced ovarian damage in rats by a gonadotropin-releasing hormone agonist. Fertil. Steril. 93(5), 1609-1614

[66] Sznitowska M., Klunder M., Placzek M., Paclitaxel Solubility in Aqueous Dispersions and Mixed Micellar Solutions of Lecithin, Chem. Pharm. Bull. 2008, 56(1), 70-74

[67] Kim S.C., Jaewon Y., Lee J.W., Seok P.E., Cheol C.S., Sensitive HPLC method for quantitation of paclitaxel (Genexol囚) in biological samples with application to preclinical pharmacokinetics and biodistribution, J. Pharmaceut. Biomed. 2005, 39(1-2), 170-176

[68] Haruo Y., Mihoko N., Mitsuhiro W., Ken’ichiro N., Simultaneous HPLC determination of paclitaxel and verapamil in rat plasma, Chromatography 2005, 26(2), 49-50

[69] Baldrey S.F., Brodie R.R., Morris G.R., Jenkins E.H., Brookes S.T., Comparison of LC-UV and LCMS-MS for the Determination of Taxol, Chromatographia, 2005, 55, S-187 - S-192 